\title{
Employees Performance Evaluation in Defense Ministry of the Republic of Indonesia based on Multicriteria Decision Making (MCDM) and System Dynamic (SD)
}



DOI: $10.46970 / 2021.27 .3 .4$

Volume 27, Number 3

September 2021, pp. 245-266

\author{
A. P. Sumarno \\ Margono Setiawan \\ Siti Aisjah \\ Sunaryo \\ Brawijaya University \\ (arpitsum@gmail.com) \\ (margono@ub.ac.id) \\ (aisjahsiti@gmail.com) \\ (sunaryo053@gmail.com)
}

This study aims at providing an evaluation of the performance of personnel in the ministry of defense. Analysis approaches employed in this study were AHP and System Dynamics within the framework of the multi-criteria decision making (MCDM) model. Furthermore, the evaluation value obtained from the performance of the ministry of defense is 3.970 included in Good category. Based on the results of the simulation of Systems Dynamics, there is an increase in the rating level from 3.97 to 4.35. Therefore, now, it is in Very Good category in which it was in Good category two years ago.

Keywords: Multicriteria Decision Making (MCDM), Analytical Hierarchy Process (AHP), System Dynamic (SD), Employee Evaluation

\section{Introduction}

The Ministry of Defense (Indonesian: Kementerian Pertahanan abbreviated Kemenhan) of the Republic of Indonesia is the implementing elements of the government led by the current-appointed Minister of Defense, under and responsible to the President (Reza, 2017). The Ministry of Defense has the task of carrying out affairs in the defense sector within the government to assist the President in administering the state government. In relation to the accountability aspect, based on the Central Government Financial Report to 2018 carried out by The Audit Board of the Republic of Indonesia (BPK RI; Badan Pemeriksa Keuangan Republik Indonesia) for all institutions/ministry especially the Ministry of Defense, the Ministry of Defense nevertheless received a Reasonable with Exceptions (Wajar Dengan Pengecualian; WDP) opinion.

The presented condition concludes that the performance of Ministry of Defense in administering good governance is not well executed and needed to be improved. One of the influential aspects is the performance of existing personnel. This study aims at providing an evaluation of the performance of personnel in the ministry of defense. The performance of these personnel needs to be evaluated to identify and provide an analysis of organizational performance in the ministry of defense. This study is expected to contribute to stakeholders in improving organizational capabilities in the ministry of defense. 
Analysis approaches employed in this study were AHP and System Dynamics within the framework of the multi-criteria decision making (MCDM) model. There are several references from previous manuscripts stating that Analytical Hierarchy Process (AHP) can be used as an evaluation model for employee performance in consulting companies (Lidinska \& Jablonsky, 2018). The development of multicriteria techniques can also be used to explain new performance appraisal models for employees (Ishizaka \& Pereira, 2016). Analytical Hierarchy Process (AHP) is a model to offer methods for portfolio management and assign weights to each company in the research object (Salardini, 2013). AHP was proposed and used to select managers in a case study of the automotive industry in Iran (Razieh \& Ahmad, 2015). AHP is used to assign weights and rankings to the National Iranian Oil Company (NIOC) (Alireza \& Seyedeh, 2015). AHP is used to measure the top factors and sub-sectors in fisheries as beneficial commodities to local resources and coastal community capability (Teniwut, Hamid, \& Makailipessy, 2019) (Teniwut, Hamid and Makailipessy, 2019). The conceptual model as an evaluation of the factors affecting employee performance and improvement initiatives can also be presented using a system dynamic approach (Alefari, Fernández Barahona, \& Salonitis, 2018). System dynamics is an analysis of economic and environmental performance evaluation of CPP under resource tax scenario (Zhao, Li, Wang, Lu, \& $\mathrm{Li}, 2020)$. A system dynamics approach is to analyze the value of social vulnerability from the presence of ISIS in Southeast Asia (Octavian, et al., 2021).

This study consists of several parts. Section two discusses the study of literature related to performance theory, human resource theory, personnel performance, and an overview of the organization of the ministry of defense. Section three discusses the mix research method, research framework, research design used. Section four describes the analysis of the results and discussion of the study in the form of influential criteria, assessment of criteria, and simulation of the results of evaluation of criteria. Section five describes the conclusions of the study.

\subsection{Performance Appraisal}

\section{Literature Review}

Performance Appraisal is a systematic evaluation to understand the performance and the ability of the employee, so that the company can plan further career development for the employee concerned (Toppo, 2012). Performance appraisal is a manager's activity to evaluate employee work performance behavior and determine further policies. Behavioral evaluation or assessment includes the assessment of loyalty, honesty, leadership, cooperation, loyalty, dedication, and employee participation (Davidescu, Apostu, Paul, \& Casuneanu, 2020). The significant value of performance appraisal is related to determining the level of independent contribution to the performance expressed in completing the tasks for which they are responsible. Performance appraisal carried out properly and professionally can increase employee loyalty and motivation. Hence, the organizational goals can also be achieved as expected. Performance appraisal makes it easier for organizations to make good decisions so that the most prominent positions are occupied by the most capable individuals (Park \& Choi, 2020).

Performance appraisal systems can be designed and managed to improve overall organizational effectiveness (Brefo-Manuh, 2017). Contemporary methods of 
performance appraisal followed by corporate companies play an important role in determining job security, pay, and other perks (Manjula, 2018). Performance appraisals can have an impact on organizational productivity ( $\mathrm{Na}-\mathrm{Nan}$, Joungtrakul, Smith, \& Sanamthong, 2021). In this study, the implementation of performance appraisal is used in determining or evaluating organizational performance in the Ministry of Defense of the Republic of Indonesia.

\subsection{Human Resource Theory}

Every company has its way of developing human resources. Human resource management is planning, organizing, directing and supervising the procurement, development, compensation, integration, maintenance and termination of labor relations to help to achieve company, individual and community goals (Tanjung, 2020). All managers get things done by delegating tasks to their employees; it requires effective human resource management (Vardarlier, 2016).

Human resource management according to Dessler is a policy and practice in mobilizing human resources or aspects related to management positions in human resources including recruitment, screening, training, awarding, and appraisal activities. Resource management is the utilization of appraisal development, remuneration, and management of individual members of the organization or group of workers (Peters, 2005). The main objective of human resource management is to increase the contribution of human resources (employees) to the organization to achieve the productivity of the organization concerned (Obi, 2015). It can be understood that all organizational activities in achieving its mission and goals are highly dependent on the humans who manage the organization. Therefore, these human resources (employees) must be managed in such a way that they are efficient and effective in achieving the mission and goals of the organization (Abdallat, Suifan, Oglah, Sweis, \& Sweis, 2020).

Several studies explain the role of human resources. Research is on the human resource challenges faced by healthcare professionals in South Asia and the identification of the appropriate strategies for better management of health care professionals (Suhail \& Azhar, 2016). Strategic Human Resources Management (SHRM) in banking organizations operating in the city of Abha Saudi Arabia and knowing the relationship between Human Resource Management (HRM) and organizational performance, in addition to knowing the main problems and challenges that may be faced (HRM) (Altarawneh, 2016). The research is about human resources and environmental management towards environmentally friendly humans (Rezaei-Moghaddam, 2016). Research in human resources is supported by the use of IT in the business processes of HR management activities (Turulja \& Bajgorić, 2016). In this study, an evaluation of the performance of human resources in the defense environment was carried out.

\subsection{Personnel Performance}

Employee performance is a result achieved by the employee in his/her work based on certain criteria applying to a particular job. Employee performance is a function of the interaction between ability and motivation (Kuranchie-Mensah \& AmponsahTawiah, 2016). The success or failure of employee performance having been achieved by the organization will be influenced by level of the employee 
performance individually or in groups. Performance is organizational behavior directly related to the production of goods or service delivery. Performance is frequently considered as the achievement of tasks, where the term task itself comes from thinking of activities required by workers (Yang, Luo, Sun, Lu, \& Kang, 2018). The success or failure of the performance having been achieved by the organization is influenced by level of the employee performance individually or in groups, where performance is measured by instruments developed in study depending on general performance measurement. Subsequently, it translated into a basic behavioral assessment which can include various things, namely: quantity of work, quality of work, opinions or statements conveyed, decisions taken in doing work, and job descriptions. Employee performance is the result of work in quality and quantity achieved by an employee in carrying out his/her duties by the responsibilities given to him. Employee performance is the result of work both quality and quantity achieved by employees in carrying out his/her duties under their respective responsibilities in a job to achieve agency goals (De Jong \& Den Hartog, 2010).

\subsection{Ministry of Defense of the Republic of Indonesia}

The Ministry of Defense of the Republic of Indonesia (Indonesian: Kementerian PertahananRepublik Indonesia) abbreviates Kemenhan RI Ministry of Defense is one of the three ministries (along with Ministry of Foreign Affairs and Ministry of Home Affairs) explicitly mentioned in the 1945 Constitution of the Republic of Indonesia. Ministry of Defense cannot be replaced or dissolved by the President. Ministry of Defense is along with Ministry of Foreign Affairs and Ministry of Home Affairs jointly execute presidential duties If both the President and Vice President of Indonesia die, resign, or are unable to perform their duties (Larosa, 2017).

\subsection{Duty and Function}

\section{- Duty}

The Ministry of Defense has the task of carrying out affairs in the defense sector in the government to assist the President in administering the state government (Larosa, 2017).

\section{- Function}

In carrying out its duties, the Ministry of Defense carries out the following functions (Rizani, 2020)

1. Formulation, determination, and implementation of policies in the defense sector.

2. The management of manufactured goods/property/property of the state is the responsibility of the ministry of defense.

3. Supervision of the implementation of tasks related to the ministry of defense.

4. Implementation of technical events from the central to the region

\subsection{Multi-Criteria Decision Making (MCDM)}

\section{Material/Methodology}

Multi-Criteria Decision Making (MCDM) is a decision-making method to determine the most suitable alternative from several alternatives based on certain 
criteria. Criteria are customarily in the form of measurements, rules, or standards used in decision making. MCDM has two categories namely, Multiple Objective Decision Making (MODM) and Multiple Attribute Decision Making (MADM) (Murat Albayrakoglu, 2007).

Multi-criteria decision making (MCDM) is a decision-making technique from several convenient choices. In the MCDM, it contains elements of attributes, objectives, and goals (Octavian, et al., 2021).

- Attribute describes, gives characteristics of an object. It is like height, length and so on.

- The objective states the direction of improvement or preference for attributes, for example maximizing age, minimizing price, and so on. The objective can also be derived from an attribute becoming an objective if the attribute is given a certain direction.

- Goals are determined in advance. For instance, a project has an objective of maximizing profit, then the project has a goal of achieving a profit of 10 million/month.

Criteria are measurements, rules or standards guiding the decision making. Decision making is done through selecting or formulating attributes, objectives and different goals. Then, attributes, objectives and goals are considered as criteria. Criteria are built from fundamental human needs and predetermined values (Triantaphyllou, Shu, Sanchez, \& Ray, 1998).

Several methods can be used to solve MCDM problems, among others (Jovanović, Shah, Vujovic, \& Krivokapic, 2014)

\section{Simple Additive Weighting Method (SAW)}

- Weighted Product Model (WPM)

- Technique for Order Preference by Similarity to Ideal Solution (TOPSIS)

- Analytic Hierarchy Process (AHP)

Multi-Criteria Decision Making (MCDM) is one of the most widely used methods in the decision-making area. The purpose of MCDM is to select the most suitable alternative from several mutually exclusive alternatives based on general performance in various criteria (or attributes) determined by the decision maker (Jayady, et al., 2021).

There are four decision-making steps in MCDM including (Permanasari, Wisaksono, \& Kusumawardani, 2020)

- Identifying the problems.

- Developing preferences.

- Evaluating alternatives.

- $\quad$ Determining the most suitable alternative. Suppose there are $\mathrm{m}$ criteria $(\mathrm{C} 1, \ldots$, $\mathrm{Cm})$ and $\mathrm{n}$ alternatives (A1,.., An).

\subsection{Analytical Hierarchy Process (AHP)}

Analytical Hierarchy Process (AHP) is a method for resolving a complex situation that is unstructured into several components in a hierarchical arrangement, by providing subjective values regarding the relative importance of each variable, and determining which variable has the absolutist priority to affect the outcome at the 
situation (Saaty T. L., 1980). The decision-making process is selecting the most suitable alternative. It is like structuring the problem, determining alternatives, assigning probability values to alternative variables, determining values, time preference requirements, and risk specifications. Regardless of the width of the alternatives that can be determined or the detailed assessment of the probability values, the remaining limits are the basis for comparisons in the form of a single criterion.

$\begin{aligned} & \text { MCDA tool that uses a } \\ & \text { hierarchical problem } \\ & \text { decomposition }\end{aligned}$
$\begin{aligned} & \text { Local priority weights } \\ & \text { from Pair-wise } \\ & \text { Comparative Method } \\ & \text { (PCM) of Judgment } \\ & \text { Global priority weight } \\ & \text { hierarchic composition } \\ & \text { (additive synthesis) }\end{aligned}$

Figure 1 Analytical Hierarchy Process (AHP) Model (Saaty T. L. 1980)

The main instrument, the Analytical Hierarchy Process (AHP), is to have a functional hierarchy with the initial input of human perception (Dekrita, Yunus, Citta, \& Yamin, 2018). With a hierarchy, a complex and unstructured problem can be solved and arranged in a hierarchical form. The Analytic Hierarchy Process (AHP) has an axiomatic basis consisting of (Vachnadze, 2016)

- Reciprocal Comparison, in which the formed pairwise comparison matrix must possess the contradictory character. For example, if $\mathrm{A}$ is $\mathrm{f}$ times more important than B then B is $1 / \mathrm{f}$ times more important than A.

- Homogeneity means similarity-making comparisons. For example, it is impossible to compare oranges to tennis balls in terms of taste, but it is more relevant in terms of weight.

- Dependence, it means that each level has a relationship (complete hierarchy) although it does not rule out that there is an imperfect relationship (incomplete hierarchy).

- Expectancy, it means that the increase of expectations and preferences in decision making. Assessment can be in the form of quantitative or qualitative data.

- The stages of decision making in the AHP method consist of several things, namely (Saaty \& Vasgas, 2006)

1. Defining the problem and determining the desired solution.

2. Creating a hierarchical structure starting with a general goal, followed by the criteria and options that you want to rank for.

3. Forming a pairwise comparison matrix describing the relative contribution or influence of each element for each objective or criterion level above it. Comparisons are performed based on the choices or considerations of decision 
makers in assessing the level of importance of an element compared to other elements.

4. Normalizing data by dividing the value of each element in the paired matrix by the total value of each column.

5. Calculating the value of the eigenvector and test its consistency. If an inconsistency happens, data collection (preference) needs to be repeated. The intended eigenvector value is the maximum eigenvector value obtained using tools or manually.

6. Repeating steps 3, 4, and 5 for all levels of the hierarchy.

7. Calculating the eigenvectors of each pair wise comparison matrix. The eigenvector value is the weight of each element. This step is to synthesize options prioritizing elements at the lowest level of the hierarchy until the goal is achieved.

8. Testing the consistency of the hierarchy. If it does not match the $\mathrm{CR}<0.100$, the assessment must be repeated.



Figure 2 Hierarchy Model in AHP. (Vachnadze, 2016)

The research objectives and procedures are described in the formula

- $\quad$ Make a Pair Comparison Matrix (Wang \& Duan, 2019).

$$
\begin{aligned}
& A=a_{i m} \\
& =\left[\begin{array}{cccc}
1 & a_{12} & \ldots & a_{1 n} \\
\frac{1}{a_{12}} & 1 & \ldots & a_{2 n} \\
\ldots & \ldots & \ldots & \ldots \\
\frac{1}{a_{1 n}} & \frac{1}{a_{2 n}} & \ldots & 1
\end{array}\right]
\end{aligned}
$$

$\mathrm{i}, \mathrm{m}=1,2, \ldots \ldots, \mathrm{n}=$ index of related criteria.

- Make a Criteria Value Matrix.

- Make an Addition Matrix for Each Line.

- Calculation of Consistency Index (CI) and Consistency Ratio (CR).

$$
\mathrm{CI}=\frac{\lambda m a k s-n}{n}
$$

$\mathrm{CR}=\frac{C I}{R I}$ 
$\mathrm{N}=$ Number of Elements,

$\mathrm{RI}=$ Random Consistency Index.

If the CR ratio is 0.1 (i.e., 10\%), the matrix is said to be consistent and the decision $\mathrm{W}$ is accepted. On the other hand, CR beyond that implies too many contradictions in the matrix. Anticipation of the latter situation is to review the matrix, then revise the weights loaded by the vector.

Table 1 Random Index Value

\begin{tabular}{|c|c|c|c|c|c|c|c|c|c|c|}
\hline $\mathbf{N}$ & $\mathbf{3}$ & $\mathbf{4}$ & $\mathbf{5}$ & $\mathbf{6}$ & $\mathbf{7}$ & $\mathbf{8}$ & $\mathbf{9}$ & $\mathbf{1 0}$ & $\mathbf{1 1}$ & $\mathbf{1 2}$ \\
\hline $\mathbf{R I}$ & 0.58 & 0.9 & 1.12 & 1.24 & 1.32 & 1.41 & 1.49 & 1.51 & 1.53 & 1.56 \\
(Saaty T. L., 1980)
\end{tabular}

\subsection{System Dynamics}

The System Dynamics Society offers an updated definition of System dynamics that $\mathrm{SD}$ is "a methodology for studying and managing complex feedback systems". System Dynamics was first introduced by Jay W. Forrester in the 1950s. System Dynamics is a method of solving complex problems resulting from the causal tendencies of various variables in the system. The system dynamics method was first applied to management problems such as inventory fluctuations, labor instability, and declining market share. From the system dynamics in the form of a causal diagram, a flowchart is built to describe the simulation variables, parameterization, and model formulation for simulation (Forrester, 1994). The processes that occur in the real world must be understood to create a logical model that resembles reality. This understanding can be obtained by distinguishing the causal variable and/or by distinguishing the dependent and independent variables (Sterman, Henderson, Beinhocker, \& Newman, 2007).Variables in System Dynamics are explained in Table 2.

Table 2 The Symbols in System Dynamics Model

\begin{tabular}{|l|l|l|}
\hline Variable & Symbol & \multicolumn{1}{c|}{ Explanation } \\
\hline \multirow{2}{*}{ Level } & & $\begin{array}{l}\text { This symbol represents the accumulated quantity that has accumulated } \\
\text { over time. This condition may change in value in line with changes in } \\
\text { tariffs }\end{array}$ \\
\hline Rate & $\searrow$ & $\begin{array}{l}\text { This symbol represents the flow rate which can change the value of the } \\
\text { level }\end{array}$ \\
\hline Auxiliary & & $\begin{array}{l}\text { This symbol represents an auxiliary variable containing a formula that can } \\
\text { be inputted at a rate }\end{array}$ \\
\hline
\end{tabular}

Source: (Sushil, 1993)

The System Dynamics model representing the structure of the feedback diagram is a causal diagram or commonly known as a Causal Loop Diagram (CLD). This diagram shows the direction of the variable change flow as well as its polarity. The flow polarity is divided into positive and negative. Another diagram that also describes the structure of a dynamic system is a flow chart. Flowcharts represent the relationships between variables in a causal diagram more clearly, using certain 
symbols for the various variables involved (Sushil, 1993). The arrows indicate the causing and/or effective variables. The arrow indicates the cause, while the other side shows the effect.



Figure 3 System Dynamics Modelling

Source: (Qiu, Shi, \& Shi, 2015)

\subsection{Research Method}

The research method serves as the main guideline in researching a basic reference. This study uses a mixed-method approach by starting with collecting data such as words and pictures from manuscripts, interviews, field notes, documents, to be described to provide clarity to the existing reality. In this study, data analysis used expert choice tools for AHP and Stella for system dynamics supported by Microsoft Excel.

Research instrument is a tool used to collect research data, both qualitative and quantitative data. The data is said to be at the nominal level or nominal scale if the number serves for identification, namely distinguishing other types of subjects. Differences in numbers only indicate the existence of separate and unequal objects or subjects.

Table 3 Scale and Level Analysis

\begin{tabular}{|c|c|c|c|}
\hline Saaty Scale (AHP) & Score Likert & Score Probability & Category \\
\hline 1 & 1 & $0-1$ & Very Low \\
\hline 3 & 2 & $1,001-2$ & Low \\
\hline 5 & 3 & $2,001-3$ & Moderate \\
\hline 7 & 4 & $3,001-4$ & Good \\
\hline 9 & 5 & $4,001-5$ & Very Good \\
\hline
\end{tabular}

Source: (Maksum, Luddin, \& Idri, 2019)

In this study, the measurement scale employed is Likert scale. This scale is utilized by the researcher for the following reasons: (1) providing many conveniences; (2) providing excellent reliability in sorting subjects based on perception; (3) providing flexibility compared to other techniques; (4) it is applicable in various situations. In data processing, the Likert scale is included in the interval scale. The distribution of questionnaires to several respondents contains items from statement indicators on research variables to obtain answers following the respondents' perceptions.

The research site in this study is within the Ministry of Defense by involving all Work Units within the Ministry of Defense consisting of all employees of echelon III and below in each Work Unit. 
In this study, the population used was all employees who served in the Ministry of Defense, both TNI and Civil Servants of echelon III and below totaling 4,647 people, details are contained in the appendix, while the general recapitulation is as listed in the Table below.

Table 4 Total Population of Research Subjects

\begin{tabular}{|c|l|c|c|c|}
\hline No & Source/Levels & Tni & Civil Servant & Total \\
\hline 1. & Echelon Iii & 689 & 36 & 725 \\
\hline 2. & Echelon Iv And Below & 929 & 2,993 & 3,922 \\
\hline & Total & $\mathbf{1 , 6 1 8}$ & $\mathbf{3 , 0 2 9}$ & $\mathbf{4 , 6 4 7}$ \\
\hline
\end{tabular}

Of the total population of 4,647 people taking samples using a percentage error rate of 5\%, the sample size is 368 employees of echelon III and, below, consisting of: 166 TNI and 202 Civil Servants (echelon III and below), with details as listed in the following Table.

Table 5 Total of Research Respondents

\begin{tabular}{|c|l|c|c|c|}
\hline No & Source/Levels & Tni & Civil Servant & Total \\
\hline 1. & Echelon Iii & 118 & 8 & 126 \\
\hline 2. & Echelon Iv & 27 & 19 & 46 \\
\hline 3. & Organizer & 3 & 57 & 60 \\
\hline 4. & Processor & 11 & 89 & 100 \\
\hline 5. & Administrator & 7 & 29 & 36 \\
\hline & Total & $\mathbf{1 6 6}$ & $\mathbf{2 0 2}$ & $\mathbf{3 6 8}$ \\
\hline
\end{tabular}

Determination of the number of TNI (166 people) and Civil Servant(202 people) from a total sample of 368 people based on the percentage of the number of TNI and Civil Servant from each Echelon working in the Ministry of Defense, so it is hoped that representatives from each section can be fulfilled. These respondents were used to provide scores for the evaluation results in the study, while the weighting of criteria and sub-criteria were carried out by three expert judgments with doctoral classification.

\subsection{Research Objective}

This research has objectives, namely

- Identifying criteria. The identification of criteria was obtained from several previous studies, books, and some opinions from experts.

- Carrying out the weighting of the evaluation assessment criteria and scoring. The weighting of the criteria that have been identified employing the AHP method by the expert. Subsequently, an evaluation assessment was carried out employing a Likert scale.

- Model development and simulation. The model development is carried out by providing an analysis of the relationship between the criteria and sub-criteria in 
the system dynamics followed by simulation analysis of the results of the performance evaluation of the ministry of defense adopting the model.



Figure 4 Research Flowchart

\subsection{Criteria Identification}

\section{Result and Discussion}

In a multi-criteria approach to evaluating employee performance, criteria are needed. Identification of criteria and sub-criteria taken into consideration in evaluating work performance. The identification of criteria and sub-criteria were obtained by reviewing literature from books, journals and previous research manuscripts, as well as several expert opinions. From the criteria and sub-criteria that have been obtained, it will be identified how the relationship between the criteria and sub-criteria through a hierarchical system will be identified.

Based on the results of the identification carried out by experts supported by literature studies, several criteria and sub-criteria were obtained related to evaluating the employee performance in the environment of Ministry of Defense:

Table 6 Identification of Research Criteria and Sub-Criteria

\begin{tabular}{|c|c|c|c|}
\hline No & Criteria & Sub-criteria & Code \\
\hline \multirow{5}{*}{1.} & \multirow{5}{*}{ Servant Leadership (C1) } & Affection & C1-1 \\
\hline & & Concern & $\mathrm{C} 1-2$ \\
\hline & & Vision & C1-3 \\
\hline & & Modesty & C1-4 \\
\hline & & Trust & $\mathrm{C} 1-5$ \\
\hline \multirow{5}{*}{2.} & \multirow{5}{*}{ Employee Performance (C2) } & Work Quantity & $\mathrm{C} 2-1$ \\
\hline & & Work Quality & $\mathrm{C} 2-2$ \\
\hline & & Work Efficiency & $\mathrm{C} 2-3$ \\
\hline & & Cooperation & $\mathrm{C} 2-4$ \\
\hline & & Discipline & C2-5 \\
\hline \multirow{3}{*}{3.} & \multirow{3}{*}{ Employee Competence (C3) } & Intellectual & C3-1 \\
\hline & & Emotional & C3-2 \\
\hline & & Social & C3-3 \\
\hline
\end{tabular}


Based on the Table above, there are several main criteria related to evaluation of employee performance within the ministry of defense, namely: 1) Servant Leadership (C1); 2) Employee Performance (C2); 3) Employee competence (C3). The Servant leadership criteria (C1) are divided into five sub-criteria, namely Affection, Concern, Vision, Modesty, Trust. Employee Performance Criteria (C2) consists of five sub-criteria, namely Quantity of Work, Quality of Work, Work efficiency, Cooperation, Discipline. Competent employee criteria (C3) are divided into three sub-criteria, namely Intellectual, Emotional, Social.

Furthermore, the criteria and sub-criteria are arranged in a hierarchical model as the following Figure 5.



Figure 5 Hierarchical Model for Performance Evaluation Criteria and Sub-Criteria

\subsection{The Results of the Weighting and Scoring Analysis}

To determine the criteria affecting the performance evaluation within the Ministry of Defense, it can be identified from the weight of each. The weight of each criterion is determined by the results of the pair wise comparison of each criterion obtained through the Phase II questionnaire. The questionnaire was processed employing the help of Expert Choice software. This data processing step starts by compiling a hierarchy, conducting pair wise comparisons, determining priorities, and incorporating respondents' opinions.

The questionnaire processing from Expert Choice will result in the weight of each criterion with a different inconsistency ratio. Inconsistency ratio is a parameter used to check whether pair wise comparisons in the questionnaire have been carried out are consistent or not. The results are declared to be consistent if they have a small inconsistency ratio value of 0.1 . If the inconsistency ratio value is greater than 0.1 , the questionnaire must be revised again. Revisions are carried out until the consistency level is less than 0.1. After revision, the resulting weight for each criterion is presented numerically and graphically.



Figure 6 Weighting Results on Evaluation Criteria 
The evaluation criteria for evaluating the performance of personnel within the ministry of defense consist of three main criteria. Based on the results of the study in the Figure 6 above, it is known that the criteria for employee performance and employee competence have the same weight, namely 0. 429. While the Servant leadership criteria weight of 0.143 . Furthermore, the relationship between these criteria has a consistency ratio (CR) value of 0.001 .



Figure 1 Weighting Results on Servant Leadership Sub-Criteria

In Figure 7, the servant leadership criteria for evaluating employee performance within the ministry of defense consists of five sub-criteria. The weighting results of the sub-criteria of vision have the highest weight value of 0.242 . The sub-criteria of affection have the lowest weight value of 0.121 . Furthermore, the results of pair wise comparisons have a consistency ratio (CR) value of 0.09 .



Figure 8 Weighting Results on Employee Performance Sub-Criteria

In Figure 8, the employee performance criteria for evaluating performance of employees within the ministry of defense consists of five sub-criteria. The weighting results of the sub-criteria of work efficiency have the highest weight value of 0.388 . The sub-criteria of work quantity have the lowest weight value of 0.051 . Furthermore, the results of pair wise comparisons have a consistency ratio (CR) value of 0.08 .



Figure 9 Weighting Results on Employee Competence Sub-criteria

In Figure 9, the employee competence criteria for evaluating performance of employees within the ministry of defense consists of three sub-criteria. The weighting results of the sub-criteria of Intellectual have the highest weight value of 0.550 . The sub-criteria of social have the lowest weight value of 0.210 . Furthermore, the results of pair wise comparisons have a consistency ratio $(\mathrm{CR})$ value of 0.02 . 
Table 7 Weighting Results Performance Evaluation Criteria and Sub-Criteria

\begin{tabular}{|c|c|c|c|c|c|}
\hline No & Criteria & Sub-criteria & Code & Local Weight & Overall Weight \\
\hline \multirow[t]{5}{*}{1} & \multirow{5}{*}{$\begin{array}{l}\text { Servant Leadership (C1) } \\
0,143\end{array}$} & Affection & C1-1 & 0,121 & 0,017 \\
\hline & & Concern & $\mathrm{C} 1-2$ & 0,221 & 0,032 \\
\hline & & Vision & $\mathrm{C} 1-3$ & 0,242 & 0,035 \\
\hline & & Modesty & $\mathrm{C} 1-4$ & 0,185 & 0,026 \\
\hline & & Trust & $\mathrm{C} 1-5$ & 0,231 & 0,033 \\
\hline \multirow[t]{5}{*}{2} & \multirow{5}{*}{$\begin{array}{l}\text { Employee Performance }(\mathrm{C} 2) \\
0,429\end{array}$} & Work Quantity & $\mathrm{C} 2-1$ & 0,051 & 0,022 \\
\hline & & Work Quality & $\mathrm{C} 2-2$ & 0,286 & 0,123 \\
\hline & & Work Efficiency & $\mathrm{C} 2-3$ & 0,388 & 0,166 \\
\hline & & Cooperation & $\mathrm{C} 2-4$ & 0,119 & 0,051 \\
\hline & & Discipline & $\mathrm{C}-25$ & 0,157 & 0,067 \\
\hline \multirow[t]{3}{*}{3} & \multirow{3}{*}{$\begin{array}{l}\text { Employee Competence (C3) } \\
0,429\end{array}$} & Intellectual & C3-1 & 0,550 & 0,236 \\
\hline & & Emotional & C3-2 & 0,240 & 0,103 \\
\hline & & Social & C3-3 & 0,210 & 0,090 \\
\hline
\end{tabular}

\section{Weight of Sub-criteria}



Figure 10 Weighting Results Performance Evaluation Criteria and Sub-Criteria

The calculation results on the overall weights for the performance evaluation subcriteria in the Ministry of Defense can be seen in Figure 10 and Table 7. Table 7and Figure 10 explain the overall weight value and priority of each level of criteria. The results of the AHP weighting explain the five most influential sub-criteria in the assessment, namely: 1) Sub-criteria of Intellectual with a weight of 0.236 ; 2) Subcriteria of Work Efficiency with a weight of 0.166; 3) Sub-criteria Work Quality with a weight of 0.123 ; 4) Sub-criteria Emotional with a weight of $0.103 ; 5$ ) Subcriteria Social with a weight of 0.090 .

The next step is to provide a scoring value for the evaluation of performance appraisals within the ministry of defense. Each weighted value of the sub-criteria and criteria will be multiplied by the score made by the respondent. The result of the multiplication is the result of the initial assessment of the performance appraisal evaluation. 
Table 8 Results of Performance Evaluation Assessment on Servant Leadership Criteria

\begin{tabular}{|l|c|c|c|c|}
\hline \multicolumn{1}{|c|}{ Criteria } & Weight & Score & Results & Category \\
\hline Affection $(\mathrm{C} 1-1)$ & 0,127 & 3,235 & 0,409 & \\
\cline { 1 - 3 } Concern $(\mathrm{C} 1-2)$ & 0,233 & 4,024 & 0,938 & \\
\cline { 1 - 3 } Vision $(\mathrm{C} 1-3)$ & 0,202 & 3,781 & 0,765 & \multirow{2}{*}{ Good } \\
\cline { 1 - 3 } Modesty (C1-4) & 0,187 & 4,113 & 0,767 & \\
\cline { 1 - 3 } Trust (C1-5) & 0,251 & 4,228 & 1,063 & \\
\cline { 1 - 3 } Evaluation Result & 1,000 & & $\mathbf{3 , 9 4 3}$ & \\
\hline
\end{tabular}

Based on Table 8, the results of the respondent's questionnaire can be seen that the performance evaluation value of the Servant Leadership (C1) criteria is 3,943 in the Good category. The highest score for the Servant Leadership criteria is in the subcriteria of Trust (C1-5) with a value of 1,063.Furthermore, the sub-criteria of Affection (C1-1) has the lowest value of 0.409 .

Table 9 Results of Performance Evaluation Assessment on Employee Performance Criteria

\begin{tabular}{|l|c|c|c|c|}
\hline \multicolumn{1}{|c|}{ Criteria } & Weight & Score & Results & Category \\
\hline Work Quantity (C2-1) & 0,059 & 4,260 & 0,252 & \\
\hline Work Quality (C2-2) & 0,298 & 4,115 & 1,224 & \\
\cline { 1 - 4 } Work Efficiency (C2-3) & 0,338 & 4,231 & 1,430 & \multirow{2}{*}{ Very Good } \\
\cline { 1 - 4 } Cooperation (C2-4) & 0,136 & 4,318 & 0,589 & \multirow{2}{*}{0,526} \\
\cline { 1 - 3 } Discipline (C2-5) & 0,169 & 3,116 & $\mathbf{4 , 0 2 2}$ & \\
\cline { 1 - 3 } Evaluation Result & 1,000 & & \\
\hline
\end{tabular}

Based on Table 9, the results of the respondent's questionnaire can be seen that the performance evaluation value of the Employee Performance (C2) criteria is 4,022 in the Very Good category. The highest score for the Employee Performance criteria is in the sub-criteria of Work Efficiency (C2-3) with a value of 1,430.Furthermore, the sub-criteria of Work Quantity (C2-1) has the lowest value of 0.252.

Table 10 Results of Performance Evaluation Assessment on Employee Competence Criteria

\begin{tabular}{|l|c|c|c|c|}
\hline \multicolumn{1}{|c|}{ Criteria } & Weight & Score & Results & Category \\
\hline Intellectual (C3-1) & 0,550 & 3,755 & 2.065 & \\
\cline { 1 - 4 } Emotional (C3-2) & 0,240 & 4,088 & 0.981 & \multirow{2}{*}{ Good } \\
\cline { 1 - 4 } Social (C3-3) & 0,210 & 4,277 & 0.898 & \\
\cline { 1 - 3 } Evaluation Result & 1,000 & $\mathbf{3 . 9 4 5}$ & \\
\hline
\end{tabular}

Based on Table 10, the results of the respondent's questionnaire can be seen that the performance evaluation value of the Employee Competence (C3) criteria is 3,945 in the Good category. The highest score for the Employee Performance criteria is in the sub-criteria of Intellectual (C3-1) with a value of 2,065.Furthermore, the subcriteria of Social (C3-3) has the lowest value of 0.898 . 
Table 11 Results of the Performance Evaluation Assessment in the Ministry of Defense

\begin{tabular}{|l|c|c|}
\hline \multicolumn{1}{|c|}{ Criteria } & Results & Category \\
\hline Servant Leadership $(\mathrm{C} 1)$ & 3.943 & Good \\
\hline Employee Performance (C2) & 4.022 & Very Good \\
\hline Employee Competence (C3) & 3.945 & Good \\
\hline Evaluation Result & $\mathbf{3 . 9 7 0}$ & Good \\
\hline
\end{tabular}

Based on Table 11, the results of the respondent's questionnaire can be seen that the performance evaluation value of the ministry of defense is 3,970 in the Good category. The highest score for performance evaluation of the ministry of defense is the Employee Performance (C2) criteria with a value of 4,022 in the Very Good category. Furthermore, for the Servant Leadership (C1) criteria, the lowest score is 3,943 in the Good category.

\subsection{Model Development and Simulation}

The model development and simulation with system dynamics is an approach that can be used to solve complex problems and reduce the limitations of human rational behavior. Therefore, the simulation model using this system dynamics is very suitable for evaluating employee performance in the Ministry of Defense environment which demands comprehensiveness although there are weaknesses faced in its practice, including the limited data owned by each organization. However, this approach can be used to minimize these limitations, so that the behavior of the system generated by simulation is expected to be close to reality.

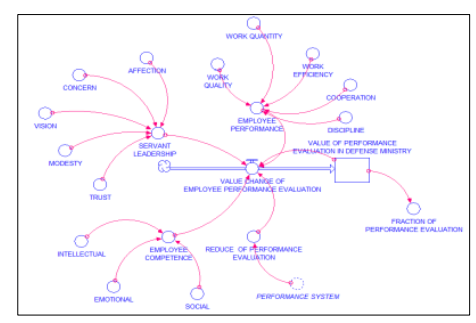

Figure 11 Stock Flow Diagram on Performance Evaluation in the Ministry of Defense

System Dynamics Modeling on the performance evaluation of personnel in the Ministry of Defense is carried out by referring to the objectives and scenarios of each model. This scenario is assumed to be the result of a simulation without any intervention or activity to strengthen the value of changes in the performance evaluation of the ministry of defense. This condition illustrates that the value of performance evaluation in the ministry of defense and its effect on related criteria. Model development is used to determine behavioral patterns and relationships between variables in the simulation determining the suitability of the model with reality conditions. With the existing modeling, it can be analyzed the value of personnel performance evaluation. In this simulation, modeling utilizes Stella software. 


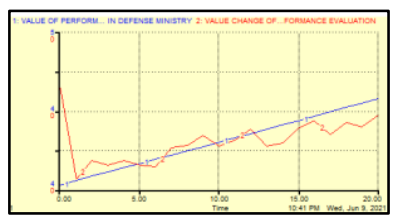

Figure 12 Simulation Value of Performance Evaluation of the Ministry of Defense

Table 12 Simulation Results of Performance Evaluation Assessment the Ministry of Defense

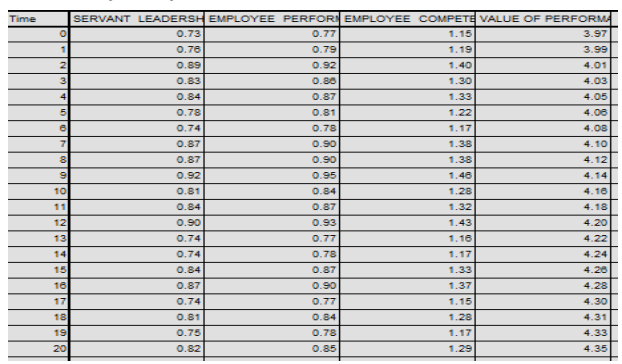

Table 12 and Figure 12 shows that there is a movement in the value of the level of performance that continues to climb. Mechanisms to improve performance within the Ministry of Defense can be carried out by simulating scenarios for improving organizational performance over the next 20 months. The maximum benefit to the goals of organizational performance can be increased through the five most influential sub-criteria, namely: 1) Intellectual; 2) Work Efficiency; 3) Work Quality; 4) Emotional; 5) Social.

Table 12 and Figure 12 explained that the simulation results of the organizational performance appraisal evaluation scenario of the ministry of defense (blue line) show that there is an increase in the rating level from 3.97 to 4.35 . Based on these results, it can be seen that there is an increase in the performance value of the Good level with a score of 3.97 to the Very Good level with a score of 4.35 with an average increase rate of 0.02 (red line).

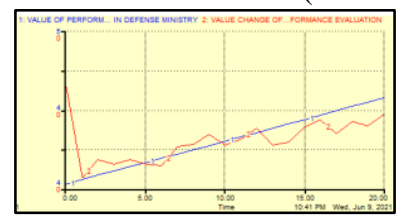

Figure 12 Simulation Value of Performance Evaluation of the Ministry of Defense

Table Figure 12 Simulation Value of Performance Evaluation of the Ministry of Defense

From Table 12 above, it can be explained that the related criteria variables show a positive response to the combination of several related sub-criteria. This condition also has a positive impact on employee performance at the Ministry of Defense so 
that from the Good category within two years it becomes the Very Good category with a score of 4.35

\section{Conclusion}

Based on the study results of evaluation on the performance of personnel in the Ministry of Defense, there are five main sub-criteria that have the most influence, namely 1) Intellectual with a weight of 0.236 ; 2) Work Efficiency with a weight of $0.166 ; 3$ ) Work Quality with a weight of 0.123 ; 4) Emotional with a weight of 0.103 ; 5) Social with a weight of 0.090. Furthermore, the results of the respondent's questionnaire can be seen that the performance evaluation value of the ministry of defense is 3.970 in the Good category. The highest score for performance evaluation of the ministry of defense is the Employee Performance (C2) criteria with a value of 4.022 in the Very Good category. Furthermore, for the Servant Leadership (C1) criteria, the lowest score is 3.943 in the Good category.

Based on the simulation results of the evaluation scenario of the organization's performance appraisal at the ministry of defense (blue line), it shows there is an increase in the rating level from 3.97 to 4.35 . These results explain there is an increase in the performance value of the Good level with a score of 3.97 to the Very Good level with a score of 4.35 with an average increase rate of 0.02 (red line). The related criteria variables indicated a positive response to the combination of several related sub-criteria. This condition also experiences a positive impact on the performance of employees at the Ministry of Defense so that within two years the good category becomes the Very Good category with a value of 4.35.

\section{Future Work (Further Research)}

In this study, explaining the results of evaluating the performance of personnel within the ministry of defense, it is necessary to re-identify the pattern of organizational behavior in the ministry of defense for further research. Second, there is a need for a simulation of performance appraisal evaluation scenarios during the new normal period after the impact of the Covid-19 pandemic ends. Third, in further research, it is necessary to analyze the influence of Servant Leadership, Employee Performance, and Employee Competence, as well as their influence on organizational performance. Fourth, in further research, it is necessary to analyze the impact of risk if there is a decrease in the value of evaluating the performance of personnel within the ministry of defense

\section{Acknowledgement}

This study was supported by Brawijaya University. The authors thank to the Indonesia Defense University. We also thank to Dr. Nengah Putra for smart discussion until this paper has been finished.

\section{References}

1. Abdallat, Y. A., Suifan, T., Oglah, K., Sweis, G., \& Sweis, R. J. (2020). The impact of human resource management practices on organizational performance in construction companies in Jordan. International Journal of Business Innovation and Research , 1(1), 1. 
2. Alefari, M., Fernández Barahona, A. M., \& Salonitis, K. (2018). Modelling manufacturing employees' performance based on a system dynamics approach. Procedia CIRP, 72, 438-443. Retrieved from https://doi.org/10.1016/j.procir.2018.03.161

3. Alireza, S., \& Seyedeh, A. P. (2015). Comparing fuzzy AHP and fuzzy TOPSIS for evaluation of business intelligence vendors. Decision Science Letters, 4(2), 137-164. doi:10.5267/j.ds1.2015.1.002

4. Altarawneh, I. I. (2016). Strategic Human Resources Management and its Impact on Performance : $\mathrm{T}$ he Case from Saudi Arabia. International Journal of Business Management and Economic Research, 7(1), 486-503.

5. Brefo-Manuh, A. B. (2017). Evaluating the Relationship between Performance Appraisal and Organizational Effectiveness in Ghana: A Comparative Analysis of Public and Private Organizations. International Journal of Economics, Commerce and Management, V (7), 532-552. Retrieved from http://ijecm.co.uk/wp-content/uploads/2017/07/5737.pdf.

6. Davidescu, A. A., Apostu, S.-A., Paul, A., \& Casuneanu, I. (2020). Work Flexibility, Job Satisfaction, and Job Performance among Romanian Employees-Implications for Sustainable Human Resource Management. Sustainability, 12, 1-53. doi:10.3390/su12156086

De Jong, J., \& Den Hartog, D. (2010). Measuring innovative work behaviour. Creativity and Innovation Management, 19(1), 23-36. doi:10.1111/j.14678691.2010.00547.x

7. Dekrita, Y. A., Yunus, R., Citta, A. B., \& Yamin, M. (2018). Integration of Balanced Scorecard and Analytical Hierarchy Process as a Tool for Determining the Priority of the Program Strategy: Case Study in Dr.Tc. Hillers Maumere Hospital . Advances in Economics, Business and Management Research (AEBMR), 92, 71-84.

8. Forrester, J. W. (1994). Sistem Dynamics, Sistems Thinking, and Soft OR. Sistem Dynamics Review Summer, 10(2), 3.

9. Ishizaka, A., \& Pereira, V. E. (2016). Portraying an employee performance management system based on multi-criteria decision analysis and visual techniques. International Journal of Manpower, 37(4), 628-659. doi:10.1108/IJM-07-2014-0149

10. Jayady, A., Hidayat, T., Qomariyah, E., B.B., S., Husain, M. N., Caniago, A., . . . S. N. (2021). Decision Support System with Multi Criteria Decision Making Technique. Journal of Physics: Conference Series, 1993, 1-9.

11. Jovanović, J. Š., Shah, H., Vujovic, A., \& Krivokapic, Z. (2014). Application of MCDM methods in evaluation of environmental impacts. International Journal for Quality Research, 8(4), 517-532.

12. Kuranchie-Mensah, E. B., \& Amponsah-Tawiah, K. (2016). Employee motivation and work performance: A comparative study of mining companies in Ghana. Journal of Industrial Engineering and Management, 9 (2), 255-309.

13. Larosa, T. (2017). The Future Defense System for the Indonesian Nation State. Jurnal Pertahanan, 3(3), 261. 
14. Lidinska, L., \& Jablonsky, J. (2018). AHP model for performance evaluation of employees in a Czech management consulting company. Central European Journal of Operations Research, 26(1), 239-258. doi:10.1007/s10100-017-04867

15. Maksum, A., Luddin, M. R., \& Idri, F. (2019). Evaluation Program for the Career Development of Indonesian Navy Civilian Personnel using the CIPP Evaluation Model and Analytical Hierarchy Process (AHP). International Journal of Recent Technology and Engineering (IJRTE), 8(4), 1309-1316.

16. Manjula, R. (2018). An Insight into the Practical Performance Appraisal Methods for the Contemporary Employees. International Journal of Multidisciplinary, 12(3), 1317-1318.

17. Murat Albayrakoglu, M. (2007). Configuring A Major Amphibious Vessel: A Multi-Criteron Decision Making Model Using the Analytic Hiearchy Process. ISAHP.

18. Na-Nan, K., Joungtrakul, J., Smith, I. D., \& Sanamthong, E. (2021). Reliability and validation of an instrument for measuring problems with performance appraisal of automotive parts manufacturing employees. International Journal of Quality and Reliability Management, 35(10), 2436-2449. doi: https://doi.org/10.1108/IJQRM-05-2020-0171

19. Obi, J. (2015). Effective Human Resources Management Practices As the Key To Organizational Performance. International Journal of Educational Research, 3(1), 1-26.

20. Octavian, A., Widjayanto, J., Putra, I. N., Purwantoro, S. A., Salleh, M. Z., Rahman, A. A., . . Baker, R. (2021). Combined multi-criteria decision making and system dynamics simulation of social vulnerability in southeast Asia. Decision Science Letters, 10(3), 323-336.

21. Park, S., \& Choi, S. (2020). Performance feedback, goal clarity, and public employees' performance in public organizations. Sustainability, 12(7), 1-18. doi:10.3390/su12073011

22. Permanasari, A. E., Wisaksono, M., \& Kusumawardani, S. S. (2020). Multi Criteria Decision Making to Support Major Selection of Senior High School. IJITEE (International Journal of Information Technology and Electrical Engineering), 3(4), 128.

23. Peters, M. (2005). Entrepreneurial skills in leadership and human resource management evaluated by apprentices in small tourism businesses. Education and Training, 47(8-9), 575-591. doi:10.1108/00400910510633125

24. Qiu, Y., Shi, X., \& Shi, C. (2015). A System Dynamics Model for Simulating the Logistics Demand Dynamics of Metropolitans: A Case Study of Beijing, China. Journal of Industrial Engineering and Management, 8(3), 783-803.

25. Razieh, K., \& Ahmad, M. (2015). An IF-DEMATEL-AHP based on Triangular Intuitionistic Fuzzy Numbers (TIFNs). Decision Science Letters, 4(2), 237-246. doi:10.5267/j.dsl.2014.11.002.

26. Reza, B. I. (2017). The Development of the State-Sponsored Militia as the Implementation of the Total People's Defense and Security System in Indonesia. Indonesia Law Review, 2, 155-177. 
27. Rezaei-Moghaddam, K. (2016). Green management of human resources in organizations: An approach to the sustainable environmental management. Journal of Agricultural Technology, 12(3), 509-522.

28. Rizani, N. (2020). Prabowo Subianto and Indonesia's Geostrategic Defence Outlook : Between US-China and ASEAN. THC Insights, 09.

29. Saaty, T. L. (1980). The Analytical Hierarchy Process. New York: McGraw Hill.

30. Saaty, T. L., \& Vasgas, L. G. (2006). Decision Making with the Analytical Hierarchy Process (AHP). Pittsburg: Springer Science Bussiness Media.

31. Salardini, F. (2013). An AHP-GRA method for asset allocation: A case study of investment firms on Tehran Stock Exchange. Decision Science Letters, 2(4), 275-280. doi:10.5267/j.ds1.2013.06.002

32. Sterman, J. D., Henderson, R., Beinhocker, E., \& Newman, L. (2007). Getting big too fast: strategic dynamics with increasing returns and bounded rationally . Management Science, 53(4), 683-696.

33. Suhail, A., \& Azhar, A. (2016). Managing human resources in public health care system in South Asia: Case study of Pakistan. South Asian Journal of Human Resources Management, 3(1), 75-83.

34. Sushil. (1993). System Dynamics: A Practical Approach for Managerial Problems. Wiley Eastern Limited.

35. Tanjung, B. N. (2020). Human Resources (HR) In Education Management. Budapest International Research and Critics in Linguistics and Education (BirLE) Journal, 3(2), 1240-1249. doi:10.33258/birle.v3i2.1056.

36. Teniwut, W. A., Hamid, S. K., \& Makailipessy, M. M. (2019). Selecting top fisheries sub-sector in each sub-district for sustainable development of archipelagic region in Indonesia: A hybrid fuzzy-MCDM approach. Decision Science Letters, 8(4), 393-410. doi:10.5267/j.ds1.2019.6.001

37. Toppo, M. L. (2012). From Performance Appraisal to Performance Management. IOSR Journal of Business and Management, 3(5), 1-6. doi:10.9790/487x-0350106

38. Triantaphyllou, E., Shu, B., Sanchez, S. N., \& Ray, T. (1998). Multi-Criteria Decision Making : An Operations Research Approach. Electronics, 15, 175186.

39. Turulja, L., \& Bajgorić, N. (2016). Human Resources or Information Technology: What is More Important for Companies in the Digital Era? Business Systems Research Journal, 7(1), 35-45. doi:10.1515/bsrj-2016-0003

40. Vachnadze, R. (2016). Priorization of Performance Measures using Analytical Hierarchy Process. International Journal of the Analytic Hierarchy Process, 8(3), 408-501.

41. Vardarlier, P. (2016). Strategic Approach to Human Resources Management During Crisis. Procedia - Social and Behavioral Sciences, October (235), 463472. doi:10.1016/j.sbspro.2016.11.057.

42. Wang, X., \& Duan, Q. (2019). Improved AHP-TOPSIS Model for The Comprehensive Risk Evaluation of Oil And Gas Pipelines. Petroleum Science, 16, 1479-1492. 
43. Yang, B., Luo, Y., Sun, Y., Lu, W., \& Kang, L. (2018). Simulation and Experimental Research on Magnetic Circuit of MRF Yield Stress Testing Device. Journal of Failure Analysis and Prevention, 18, 1286-1292. doi:https://doi.org/10.1007/s11668-018-0520-7

44. Zhao, H., Li, B., Wang, X., Lu, H., \& Li, H. (2020). Evaluating the performance of China's coal-fired power plants considering the coal depletion cost: A system dynamic analysis. Journal of Cleaner Production, 275, 122809. Retrieved from https://doi.org/10.1016/j.jclepro.2020.122809

\section{About Our Authors}

Ari P. Sumarno a doctoral student from Brawijaya University, also a lecturer at the Indonesia Defense University (IDU). $\mathrm{He}$ is an active soldier in the Indonesian Army with the rank of Colonel. He is also an active researcher in the field of Organizational Behavior.

Margono Setiawan he is one of the lecturers in the Department of Management, Faculty of Economics and Business, Universities Brawijaya. He is also an active researcher in the fields of Human resource Planning, Human Resource Management, Organizational Behavior, and Strategic Management.

Siti Aisjah she is a lecturer at Brawijaya University. She is the head of the Management S1 Study Program. She is a doctoral graduate from Brawijaya University majoring in Strategic Financial Management. She is also a lecturer in Financial Management, Banking Management, Financial Planning, Operation Research.

Sunaryo he is a lecturer at Brawijaya University. He earned a Bachelor's degree (S1) from Brawijaya University Malang, and a Master of Management (MM) degree from Gajah Mada University. Doctoral Degree (Dr) from University Sains Malaysia. He is also a lecturer in Business Mathematics, Statistics, Strategic Marketing Management, Consumer Behavior. 